\title{
ANALISIS PENGARUH RENDAHNYA HARGA KARET TERHADAP KONDISI SOSIAL EKONOMI PETANI KARET DI KECAMATAN PELEPAT KABUPATEN BUNGO
}

\author{
Muhammad Yahya, Fikriman, Evo Afrianto \\ Program Studi Agribisnis Fakultas Pertanian Universitas Muara Bungo \\ manfikri@ymail.com,evo_juventini@yahoo.com
}

\begin{abstract}
ABSTRAK
Penelitian ini dilaksanakan di Kecamatan Pelepat yang dilakukan mulai tanggal 10 Maret sampai 15 April 2017. Penelitian ini bertujuan untuk mengetahui Pengaruh Rendahnya Harga Karet Terhadap status sosial ekonomi masyarakat di Kecamatan Pelepat Kabupaten Bungo. Untuk mengetahui faktor sosial ekonomi yang paling dominan terpengaruh akibat rendahnya harga karet di Kecamatan Pelepat Kabupaten Bungo.

Sampel dalam penelitian diambil dari 2 desa yang dipilih secara sengaja yaitu Desa Rantau Keloyang dan Desa Senamat dengan sampel masing-masing 33 orang dan 40 orang sehingga jumlah sampel sebanyak 73 petani sampel. Untuk menganalisis pengaruh rendahnya harga terhadap kondisi sosial ekonomi menggunakan kuesioner dianalisis dengan deskriptif presentatif yang dibantu dengan penskoran yang diperoleh responden dari hasil angket yang telah diisi sedang untuk mengetahui bagaimana pengaruh kedua variabel, peneliti menggunakan teknik Analisis Regresi Linier Sederhana dan untuk mengetahui besarnya proporsi atau presentase sosial ekonomi yang dijelaskan oleh variabel rendahnya harga karet, maka dilakukan Uji F, Uji t dan Uji Koefisien Determinasi $\left(\mathrm{R}^{2}\right)$ melalui SPSS Versi 16.

Hasil penelitian menunjukkan bahwa Pengaruh rendahnya harga karet terhadap status sosial ekonomi secara keseluruhan adalah kurang baik (persentase skor $=50,59 \%$ ). Secara analisis rendahnya harga karet berpengaruh terhadap faktor sosial ekonomi secara keseluruhan ( $\mathrm{t}$ hitung $=3,257>\mathrm{t}$ tabel $=1,993$ ). Adapun faktor sosial ekonomi yang terpangaruh adalah pendapatan $(\mathrm{t}$ hitung $=2,134>\mathrm{t}$ tabel $=1,993)$ dan jenis pekerjaan $(\mathrm{t}$ hitung $=-2585>\mathrm{t}$ tabel $=1,993)$ dan Jenis pekerjaan merupakan faktor sosial ekonomi yang paling dominan terpengaruh oleh rendahnya harga karet jika ditinjau dari nilai koefisien determinasi $\left(\mathrm{R}^{2}\right)$ sebesar 0,086 .
\end{abstract}

\section{Kata Kunci : Rendahnya Harga Karet, Faktor Sosial Ekonomi}

\section{PENDAHULUAN}

Komoditi karet menjadi komoditi andalan dan memegang peranan penting dalam mendorong perekonomian masyarakat dan menumbuhkan sektor industri yang mengolah karet alam menjadi jenis barang setengah jadi maupun barang jadi seperti karet busa, ban, sepatu dan jenis barang lainnya yang secara tidak langsung dapat menyerap tenaga kerja serta meningkatkan volume ekspor. Karet alam telah sejak lama menjadi komoditi trade mark dari Kabupaten Bungo.

Komoditi ini telah lama diusahakan secara turun temurun dan diperdagangkan di Kabupaten Bungo sejak jaman penjajahan Belanda sehingga pengusahaan karet dapat dikatakan telah menjadi bagian dari budaya masyarakat Bungo. Pada tahun 2015, areal perkebunan karet di Kabupaten Bungo tercatat seluas $101.851 \mathrm{Ha}$ dengan 
jumlah rumah tangga petani sebanyak 45.941 keluarga. Salah satu sentra pengasil karet di Kabupaten Bungo adalah Kecamatan Pelepat dimana sebagian besar masyarakatnya adalah masyarakat petani. Potensi pengembangan komoditi karet di Kecamatan Pelepat Kabupaten Bungo masih sangat besar dilihat dari luas wilayah Kecamatan Pelepat 22,95 \% dari luas wilayah Kabupaten Bungo. Kecamatan Pelepat adalah sentra produksi karet tebesar kedua di Kabupaten Bungo setelah Kecamatan Jujuhan. Dengan luas area pekebunan karet di kecamatan pelepat yakni 10.435 ha dan menghasilkan 3.906 ton/tahun, dengan jumlah keluarga petani 3753 yang menggantungkan hidupnya dari komoditi karet (Dinas Kehutanan dan Perkebunan Kabupaten Bungo, 2015). Dan didukung dengan Peraturan Daerah Kabupaten Bungo Nomor 9 Tahun 2013, Tentang Rencana Tata Ruang Wilayah Kabupaten Bungo Tahun 2013-2033 kecamatan pelepat merupakan Kawasan Peruntukan Industri. Seperti Industri Crumb Rubber, (industry pengolahan karet), Industri Hilir Pengolahan Crude Palm Oil (CPO) menjadi barang jadi (minyak sawit).

Dalam rentang waktu sejak tahun 2011 sampai peertengahan tahun 2014, telah terjadi perubahan yang sangat signifikan terhadap kondisi harga karet, yang mana harga karet alam yang sebelumnya mencapai sekitar Rp 37.000 per Kg SIR 20 di Tahun 2011 terus menurun hingga mencapai harga hanya sekitar Rp 17.000 per Kg SIR 20 di Tahun 2016.

Komoditas Karet yang pada saat ini mengalami penurunan harga menjadi sorotan masyarakat, karena petani karet bergantung dengan mata pencaharian sebagai penyadap karet untuk memenuhi kebutuhan sehari-hari. Penurunan harga karet menyebabkan masyarakat kesusahan untuk mendapatkan penghasilan banyak seperti dulu pada saat harga karet tinggi, khususnya petani di Kecamatan Pelepat Kabupaten Bungo.

Menurut Hendratno (2006), pada saat harga karet tinggi semua kebutuhan hidup rumah tangga petani dapat dipenuhi dari usaha tani karet. Oleh karena itu, keluarga petani lebih banyak mengalokasikan tenaga kerja keluarga produktif untuk usahatani karet.

Pada saat harga karet rendah, penghasilan dari usaha tani karet tidak mampu mencukupi kebutuhan rumah tangga petani. Namun untuk mencukupi kebutuhan rumah tangga, sebagian dari anggota keluarga petani ataupun buruh sadap terpaksa mencari penghasilan tambahan dengan bekerja sampingan di luar usaha tani karet seperti: menjadi buruh perkebunan sawit, maupun bekerja di proyek infrastruktur seperti pengaspalan jalan, penggalian pipa, dan lain sebagainya. Penurunan harga karet tersebut diduga telah memberikan berbagai pengaruh terhadap kondisi sosial ekonomi petani karet di Kecamatan Pelepat Kabupaten Bungo. Dengan turunnya harga karet penghasilan masyarakat menjadi berkurang sehingga menimbulkan pengaruh sosial ekonomi.

Sosial ekonomi menurut Abdulsyani (2002) adalah kedudukan atau posisi sesorang dalam kelompok manusia yang ditentukan oleh jenis aktivitas ekonomi, pendapatan, tingkat pendidikan, jenis pekerjaan, dan kekayaan yang dimiliki serta kesehatan. Berkaitan dengan penelitian ini yang dimaksud dengan kondisi sosial ekonomi adalah : kondisi sosial berupa latar belakang suatu keluarga yang dipandang dari tingkat pendidikan orang tua dan kesehatan sedangkan kondisi ekonomi berupa latar belakang suatu keluarga dipandang dari pendapatan keluarga, jenis pekerjaan dan kekayaan yang dimilikinya.

Adapun tujuan penelitian ini adalah untuk mengetahui Pengaruh Rendahnya Harga Karet Terhadap status sosial ekonomi masyarakat dan faktor sosial ekonomi yang paling dominan terpengaruh akibat rendahnya harga karet di Kecamatan Pelepat Kabupaten Bungo

Sehubungan dengan uraian di atas, menurunnya harga komoditas karet khususnya di Kecamatan Pelepat Kabupaten Bungo, tentu memiliki pengaruh terhadap kehidupan sosial ekonomi 
masyarakat petani karet. berdasarkan uraian latar belakang diatas, maka penulis tertarik untuk melakukan penelitian dengan judul . "Analisis Pengaruh Rendahnya Harga Karet Terhadap Kondisi Sosial Ekonomi Petani Karet di Kecamatan Pelepat"

\section{METODOLOGI PENELITIAN}

Penelitian ini dilaksanakan di Kecamatan Pelepat. Pemilihan lokasi dilakukan secara sengaja dengan pertimbangan Kecamatan Pelepat Kabupaten Bungo merupakan kecamatan sentra penghasil komoditi karet dengan jumlah produksi 3.906 ton/ tahun dari luas lahan 10.435 (ha). Penelitian dilaksanakan mulai tanggal 10 Maret sampai 15 April 2017.

Jenis data dalam penelitian ini ada dua yaitu data primer dan data sekunder : Menurut Suyanto (2005), berdasarkan derajat sumbernya, data dapat dikelompokkan menjadi dua yakni : data primer dan data sekunder. Data primer merupakan data yang di peroleh dari sumber pertama atau sumber asli (langsung dari imforman), misalnya dari individu atau perorangan dan yang lainnya yang merupakan sumber utama data penelitian. Untuk memperoleh data yang akurat maka teknik pengumpulan data dalam penelitian ini dilakukan langsung pada objek sasaran yaitu dengan menggunakan teknik Kuesioner dan Teknik Observasi,

Data sekunder merupakan data yang diperoleh dari sumber kedua atau bukan dari sumber aslinya. Data sekunder ini bisa berbentuk data yang tersaji dalam bentuk tabel, grafik, internet dan lain sebagainya. Sumber data sekunder dapat berasal dari peneliti sebelumnya, lembaga pemerintah, lembaga swasta, dan lain sebagainya.

Populasi dalam penelitian ini adalah petani karet. Menurut Arikunto (2002) populasi adalah keseluruhan objek penelitian. Apabila seseorang meneliti semua elemen yang ada dalam wilayah penelitian maka penelitiannya merupakan penelitian populasi. Studi atau penelitiannya juga disebut studi populasi atau studi sensus. Menurut sumber dari UPTB BP3K Kecamatan Pelepat jumlah petani karet yang ada di kec' 'an pelepat sebanyak 3.388 orang. \& el adalah sebagian atau wakil populasi yang diteliti (Arikunto, 2002). Besar kecilnya sampel :

a) Kemampuan peneliti dapat dilihat dari waktu, tenaga dan dana, b) Sempit luasnya wilayah pengamatan dari setiap sabjek karena hal ini banyak sedikitnya data, dan c) Besar kecilnya resiko yang ditangggung peneliti. Karena subjek dalam populasi penelitian ini sebanyak 3.388 petani karet, maka teknik pengambilan sampelnya adalah radom sampling yaitu pengambilan sampel secara acak dengan mengambil $5 \%$ dari total 2 desa yang dipilih secara sengaja sehingga jumlah sampel sebanyak 73 petani sampel. Dipilihnya 2 desa sebagai sampel yaitu desa Rantau Keloyang dan Senamat karena desa tersebut merupakan desa dengan jumlah petani karet yang paling dominan atau paling banyak diantara desa lain di Kecamatan Pelepat. Sedangkan pengambilan sampel berdasarkan Singarimbun (1989) yaitu pengambilan sampel 5-10 \% telah dapat mewakili populasi. untuk lebih jelas besarnya pengambilan sampel seperti pada tabel 1 .

Tabel 1. Pengambilan Sampel Penelitian

\begin{tabular}{|c|c|c|c|}
\hline No & Desa & $\begin{array}{c}\text { Jumlah } \\
\text { Petani } \\
\text { penyadap } \\
\text { karet (kk) }\end{array}$ & $\begin{array}{c}\text { Jumlah Petani } \\
\text { Sampel } \\
\text { penyadap karet } \\
\text { (Orang) }\end{array}$ \\
\hline 1 & $\begin{array}{l}\text { Rantau } \\
\text { keloyang }\end{array}$ & 653 & 33 \\
\hline 2 & Senamat & 793 & 40 \\
\hline & Jumlah & & 73 \\
\hline
\end{tabular}

Untuk menganalisis pengaruh rendahnya harga terhadap kondisi sosial ekonomi menggunakan kuesioner dianalisis dengan deskriptif presentatif digunakan untuk memberikan deskriptif atau pembahasan dalam penelitian ini. Langkahlangkah yang ditempuh dalam menggunakan teknik analisis ini, yaitu: 
a) Membuat tabel distribusi jawaban angket X dan Y

b) Menentukan skor jawaban responden dengan ketentuan skor yang telah ditetapkan.

c) Menjumlahkan skor jawaban yang diperoleh dari tiap-tiap responden.

d) Menurut Ali dalam Aryana (2004) langkah yang selanjutnya adalah menentukan skor tersebut kedalam rumus sebagai berikut:

$$
D P=\frac{n}{N} \times 100 \%
$$

Keterangan :

$$
\begin{aligned}
& \mathrm{DP}=\text { Deskriptif persentase } \\
& \mathrm{n}=\text { Nilai yang diperoleh } \\
& \mathrm{N}=\text { Jumlah seluruh nilai yang } \\
& \text { diharapkan }
\end{aligned}
$$

Untuk mempermudah analisis data, yang berasal dari angket bertingkat maka perlu diketahui skor yang diperoleh responden dari hasil angket yang telah diisi (Arikunto, 2002). Untuk itu perlu ditentukan kriteria penskoran sebagai berikut :

1) Untuk alternatif jawaban a diberi skor 4

2) Untuk alternatif jawaban b diberi skor 3

3) Untuk alternatif jawaban c diberi skor 2

4) Untuk alternatif jawaban d diberi skor 1

Perhitungan frekuensi persebaran hasil penelitian pada korelasi antara harga karet terhadap kondisi ekonomi petani karet. Untuk menentukan kriteria penskoran adanya hubungan rendahnya harga karet terhadap kondisi sosial ekonomi petani karet menggunakan perhitungan sebagai berikut:

1) Persentase skor maksimal $=(4: 4) \mathrm{x}$ $100 \%=100 \%$

2) Persentase skor minimal $=(1: 4) \times 100 \%$ $=25 \%$

3) Rentang $=100 \%-25 \%=75 \%$

4) Panjang kelas interval $=75 \%: 4=$ $18,75 \%$

Dengan panjang kelas interval $18,75 \%$ dan persentase skor minimal $25 \%$, maka diperoleh kelas-kelas interval sebagai berikut:

Tabel 2. Perhitungan Deskriptif Presentase

\begin{tabular}{|c|c|c|}
\hline No & Persentase & Kriteria \\
\hline 1 & $25 \%-43,75 \%$ & Tidak baik \\
\hline 2 & $43,76 \%-62,50 \%$ & Kurang baik \\
\hline 3 & $62.51 \%-81,25 \%$ & Baik \\
\hline
\end{tabular}

\begin{tabular}{|c|c|c|}
\hline 4 & $81.26 \%-100 \%$ & Sangat baik \\
\hline
\end{tabular}

Sumber: Data Analisis Penelitian, Tahun 2017

Untuk mengetahui bagaimana pengaruh kedua variabel, peneliti menggunakan teknik Analisis Regresi Linier Sederhana. Analisis regresi linier digunakan untuk mengetahui perubahan yang terjadi pada variabel dependent (faktor sosial ekonomi), nilai variable dependent berdasarkan nilai independent (rendahnya harga karet) yang diketahui. Dengan menggunakan analisis regresi linier maka akan mengukur perubahan variabel terikat berdasarkan perubahan variabel bebas. Analisis regresi linier dapat digunakan untuk mengetahui perubahan pengaruh yang akan terjadi berdasarkan pengaruh yang ada pada periode waktu sebelumnya. Untuk mengetahui sejauh mana pengaruh yang diperkirakan antara rendahnya harga karet dengan kondisi sosial ekonomi dilakukan dengan rumus regresi linier sederhana, yaitu sebagai berikut :

$$
\mathbf{Y}=\mathbf{a}+\mathbf{b X}
$$

(Sumber : Sugiyono, 2013)

Keterangan :

$\mathrm{Y}=$ Faktor Sosial Ekonomi

$\mathrm{X}=$ Rendahnya Harga Karet

a $\quad=$ Intersep

$\mathrm{b}=$ Koefisien regresi dari $\mathrm{X}$

Untuk mengetahui besarnya proporsi atau presentase sosial ekonomi yang dijelaskan oleh variabel rendahnya harga karet, maka dilakukan uji hipotesis. Adapun uji hipotesis yang dilakukan adalah :

1. Uji F

Dalam analisis regresi linier sederhana digunakan untuk mengetahui apakah variabel rendah harga berpengaruh terhadap sosial ekonomi. Uji F digunakan untuk menguji keberartian regresi. Uji $F$ dalam penelitian ini menggunakan software SPSS V 16 for windows dan datanya bersumber pada output tabel Anova, kemudian pengujian dilakukan dengan membandingkan antara Fhitung dan 
Ftabel. Pengujian menggunakan tingkat signifikansi 0,05 dengan kriteria :

Jika $\mathrm{F}_{\text {hitung }}>\mathrm{F}$ table berarti $\mathrm{H}_{0}$ ditolak, dan

Jika $\mathrm{F}$ hitung $\leq \mathrm{F}$ tablel berarti $\mathrm{H}_{0}$ diterima, (Sudjana, 2005)

2. Uji t

Selain uji $\mathrm{F}$ perlu juga dilakukan uji $\mathrm{t}$ yang digunakan untuk mengetahui pengaruh secara signifikan antara variabel bebas terhadap variabel terikat. Pengujian pada penelitian ini digunakan uji satu pihak kanan dengan tingkat kepercayaan sebesar $95 \%$. Rumus yang digunakan untuk uji t ini adalah sebagai berikut :

dengan rumus sebagai berikut :

$$
\mathbf{T}_{i}=\frac{\mathbf{b}_{\mathbf{i}}}{\mathbf{S b}_{i}}
$$

Dimana :

(Sudjana, 2005)

$\mathrm{Ti}=\mathrm{t}$-hitung

bi $=$ Koefisien regresi variabel ke -1

$\mathrm{Sbi}=$ Standar error masing-masing variabel ke-1

Jika $\mathrm{t}_{\text {hitung }} \leq \mathrm{t}_{\text {table }}$ berarti $\mathrm{H}_{1}$ ditolak, dan Jika $\mathrm{t}_{\text {hitung }}>\mathrm{t}$ tablel berarti $\mathrm{H}_{1}$ diterima, (Sudjana, 2005)

3. Uji Koefisien Determinasi $\left(\mathrm{R}^{2}\right)$ Koefisien determinasi bertujuan untuk mengukur seberapa jauh kemampuan model dalam menerangkan variasi variabel dependen. Uji Koefisien eterminasi $\left(\mathrm{R}^{2}\right)$ dalam penelitian ini menggunakan software SPSS V 16 for windows.

\section{HASIL DAN PEMBAHASAN}

\section{Kondisi Sosial Ekonomi Petani Sampel Akibat Rendahnya Harga Karet}

Faktor sosial ekonomi adalah faktor-faktor yang berasal dari segi sosial dan ekonomi yang dimiliki petani sehingga dapat mempengaruhi pandangan mereka mengenai suatu hal. Menurut Soekartawi (1988). Dalam pengambilan keputusan apakah seseorang menerima atau menolak suatu inovasi banyak tergantung pada sikap mental dan perbuatan yang dilandasi oleh situasi internal (sosial-ekonomi) orang tersebut. Hasil menunjukan rata-rata jawaban responden terhadap pengaruh rendahnya harga karet terhadap kondisi sosial ekonomi petani terlihat bahwa skor rata-ratanya adalah 2,02 yang berada pada persentase 50,59 dengan kriteria kurang baik. Sehingga dapat dikatakan bahwa kondisi sosial ekonomi petani sampel di daerah penelitian berada dalam kondisi kurang baik yang disebabkan oleh rendahnya harga. Pada saat harga karet tinggi, petani karet mempunyai status yang lebih baik dibandingkan dengan petani lainnya karena petani karet pada saat harga jual karet tinggi mempunyai pendapatan yang lebih tinggi, semua yang mereka inginkan dapat dibeli bahkan fasilitas kepemilikan seperti kendaraan bermotor dan kebutuhan lainnya dapat dibeli, sehingga pekerjaan petani karet pada saat harga tinggi mempunyai status sosial ekonomi yang lebih diharagai. Menurut Soekanto (2007) Pekerjaan seseorang, biasanya dianggap sebagai status tetap dan tertinggi, walaupun tidak senantiasa demikian halnya. Hal ini antara lain disebabkan karena penghasilan pekerjaan tertentu juga dapat menentukan tinggi rendahnya status seseorang. Adapun pengaruh rendahnya harga karet terhadap masing-masing faktor sosial ekonomi adalah sebagai berikut:

\section{Pendapatan}

Pendapatan yang dimaksud dalam penelitian adalah pendapatan yang diperoleh petani sampel dalam berusahatani karet yang berguna untuk memenuhi kebutuhan hidup. Dari jumlah pendapatan yang diperoleh inilah yang digunakan 
untuk memenuhi semua kebutuhan dalam keluarga mulai dari pemenuhan akan kebutuhan pokok seperti makanan, minuman, pakaian dan tempat tinggal sampai pada pemenuhan kebutuhan pendidikan bagi anak.

Berdasarkan penelitian dari hasil kuisioner dari 8 indikator pendapatan yang ditanyakan, skor rata-rata indikator pertanyaan terendah terdapat pada pertanyaan 1 dimana semua responden bekerja sebagai petani karet diatas 4 tahun, sedangkan Skor tertinggi terdapat pada pertanyaan item 8 yaitu lahan yang dikelola petani sampel pada umumnya (42 orang) adalah lahan dengan bagi hasil yaitu $2: 1$ sehingga pendapatan yang diterima kecil ditambah lagi dengan murahnya harga karet. Berdasarkan hasil penelitian rata-rata jawaban responden bahwa pengaruh rendahnya harga karet terhadap tingkat pendapatan adalah 1,75 dengan persentase $43,84 \%$ dan berada pada kriteria kurang baik. Sehingga dapat dinyatakan bahwa pendapatan berada pada kondisi kurang baik serta tidak ada petani sampel yang mempunyai pendapatan dalam keadaan sangat baik. Dari hal diatas maka dapat dikatakan bahwa pendapatan petani sampel di daerah penelitian akibat rendahnya harga berada pada kondisi kurang baik. Adapun pendapatan yang diterima petani sebelum turunnya harga adalah rata-rata diatas $\mathrm{Rp}$ 2.000.000., dan setelah turunnya harga jual karet pendapatan yang diterima petani sampel turun menjadi dibawah $\mathrm{Rp}$ $1.500 .000,-$. Dengan demikian status atau kedudukan sosial ekonomi petani karet ditempat penelitian tergolong ekonomi sedang sampai golongan ekonomi rendah karena sebagian petani sampel hanya dapat memenuhi kebutuhan hidup pas-pasan bahkan pendapatan yang diterima lebih rendah dari keperluan hidup. Sadano (2008) menyatakan bahwa pendapatan yang diterima rumah tangga akan digunakan untuk membeli makanan, membeli pakaian, membiayai jasa pengangkutan, membayar pendidikan anak dan lain-lain, dalam mencukupi semua kebutuhanya setiap orang memerlukan pekerjaan karena dengan bekerja mereka akan memperoleh pendapatan, apabila pendapatan tersebut dapat mencukupi seluruh kebutuhan rumah tangga maka keluarga dapat dikatakan makmur.

\section{Jenis Pekerjaan}

Pekerjan atau mata pencaharian dapat diartikan sebagai pekerjaan atau pencaharian utama yang dilakukan setiap hari untuk memenuhi kebutuhan sehari-hari sehingga dapat diartikan bahwa pekerjaan atau mata pencaharian adalah usaha manusia dalam memenuhi kebutuhan hidupnya. Tapi karena rendahnya harga karet kebanyakan petani mencari inisiatif untuk menambah penghasilan melalui pekerjaan sampingan. Hasil penelitian menunjukan bahwa rata-rata jawaban responden terhadap kondisi pekerjaan sampingan petani sampel adalah sebesar 1,61 dan persentase 40,24 \% dengan kriteria tidak baik. Dari dua pertanyaan yang menjadi indikator pertanyaan kedua merupakan jawaban dengan skor yang terendah yang disebabkan oleh 21 orang petani mempunyai pekerjaan sampingan sehingga mempunyai tambahan penghasilan. Dari pertanyaan 1 dapat dijelaskan bahwa sebanayak 41 orang tidak mempunyai pekerjaan selain bertani karet. Meskipun harga karet rendah namun sebagian besar petani sampel (41 orang) tetap bertahan menjadi petani karet, hal ini dilakukan untuk memenuhi kebutuhan hidup. Berdasarkan hasil penelitian, umumnya petani yang mempunyai pekerjaan sampingan adalah petani yang mempunyai latar pendidikan yang lebih tinggi.

Semakin tinggi tingkat pendidikan yang ditempuh akan semakin luas pengetahuan dan informasi yang diperoleh sehingga dengan pengetahuan yang dimiliki akan berusaha untuk mencukupi kebutuhan hidup. Hal itu dapat menumbuhkan kesadaran, perhatian, minat dan kecakapan masyarakat untuk mencari alternatif lain untuk memenuhi kebutuhan tersebut sesuai dengan pengalaman yang dimiliki, seperti yang dikemukakan Khairuddin (1996) menyatakan bahwa tinggi rendahnya partisipasi masyarakat dapat disebabkan 
karena kemampuan yang mereka miliki, seperti pendidikan dan kesempatan untuk mendapatkan informasi. Taraf pendidikan yang rendah umumnya bergandengan dengan informasi dan pengertian yang serba terbatas, dengan demikian kesempatan pun serba terbatas. Sedangkan masyarakat yang berpendidikan tinggi cenderung mempunyai kesempatan lebih luas dalam memperoleh informasi terutama dalam hal pekerjaan.

\section{Pemilikan Kekayaan atau Fasilitas}

Pemilikan kekayaan atau fasilitas merupakan salah satu tolak ukur dari tingkat sosial ekonomi dalam masyarakat. Kepemilikan kekayaan atau fasilitas dapat dicerminkan sebagai kepemilikan faktor produksi maupun kekayaan oleh suatu rumah tangga yang pada akhirnya dapat mempengaruhi tingkat pendapatan dan konsumsi rumah tangga. Dalam penelitian ini barang-barang berharga dapat menunjukkan keadaan sosial ekonomi seseorang. Barang-barang yang berharga tersebut antara lain tanah, sawah, rumah maupun kendaraan dan lain-lain. rata-rata jawaban responden terhadap kepemilikan kekayaan atau fasilitas adalah sebesar 2,41 dan persentase 60,18 dengan kriteria kurang baik. Dari 7 item pertanyaan yang menjadi indikator pertanyaan dengan skor tertinggi terdapat pada pertanyaan 2 dengan rata-rata skor 3,63 dan persentase 90,75\% dimana sebagian responden masih menempati jenis rumah permanen dan pertanyaan 5 merupakan jawaban dengan perolehan skor terendah yaitu 1,19 dengan persentase jawaban sebesar 29,79 \% dimana sebagaian besar 63 orang responden menjawab bahwa selama rendahnya harga karet responden tidak pernah lagi menabung. Sehingga dapat disimpulkan bahwa rendahnya harga jual karet berdampak kurang baik terhadap kepemilikan kekayaan dan faslitas yang dimiliki petani sampel seperti tidak lagi ada perawatan untuk harta kekayaan yang dimiliki seprti tidak ada biaya untuk mengganti TV yang sudah rusak, bahkan ada yang sampai menjual dan tabungan yang dipunyai berangsur-angsur mulai habis. Menurut Abdulsyani (1994), bahwa pemilikan kekayaan yang bernilai ekonomis dalam berbagai bentuk dan ukuran seperti perhiasan, televisi, kulkas dan lain-lain dapat menunjukkan adanya pelapisan dalam masyarakat.

\section{Tingkat Pendidikan Anak}

Tingkat pendidikan merupakan salah satu kebutuhan manusia yang harus terpenuhi. Dengan pendidikan manusia akan mendapatkan ilmu dan mengetahui banyak wawasan. Dikalangan petani pun pendidikan juga diperlukan, untuk menjamin kehidupan yang lebih baik. Berdasarkan hasil olahan data diperoleh rata-rata jawaban responden terhadap pendidikan anak petani karet adalah 2,70 dan persentase 67,47 dengan kriteria baik. Dari pertanyaan yang diberikan sebagian besar responden (33 orang) responden menjawab bahwa dengan rendahnya harga karet, responden masih sanggup meskipun jawaban yang paling dominan sangup disanggupi. Sehingga dapat dinyatakan bahwa rendahnya harga karet tidak berdampak terhadap tingkat pendidikan anak petani sampel dalam keadaan baik. Masih baiknya pendidikan anak dalam penelitian ini karena petani sampel belum memikirkan biaya untuk sekolah anak yang disebabkan oleh anak-anak yang dimiliki masih kecil, belum sekolah dan sekolahnya masih di tingkat sekolah dasar (SD). Menurut Maftukhah (2007) dalam Lubis (2014), keadaan sosial ekonomi yang baik dapat manghambat ataupun mendorong dalam pendidikan anak.

\section{Kesehatan}

Pemenuhan kebutuhan kesehatan akan meningkat ketika secara ekonomi suatu masyarakat memiliki mata pencarian dan pendapatan yang memadai. Pendapatan 
yang memadai berhubungan erat tingkat harga dan produksi tanaman karet. Pengertian Kesehatan menurut wikipedia adalah keadaan sejahtera dari badan, jiwa, dan sosial yang memungkinkan setiap orang hidup produktif secara sosial dan ekonomis. Hasil penelitian menunjukan rata-rata jawaban responden terhadap indikator keshatan adalah 2,85 dan persentase $71,23 \%$ dengan kriteria baik. Dari pertanyaan yang disajikan pertanyaan 1 merupakan jawaban responden dengan persentase tertinggi yaitu $86,99 \%$ yang mana sebagaian besar responden memilih membeli obat diwarung sedangkan pada item pertanyaan kedua berdasarkan bisa membayar fasilitas kesehatan yang disediakan oleh pemerintah seperti BPJS dan para petani lebih memilih membeli obat ke warung. Sehingga rendahnya harga jual karet masih berpengaruh baik terhadap kesehatan petani sampel. Menurut

\section{Pengaruh Rendahnya Harga Karet Terhadap Faktor Sosial Ekonomi Petani Sampel}

Untuk melihat pengaruh rendahnya harga terhadap faktor sosial ekonomi petani karet secara keseluruhan dilakukan dengan analisis regresi sederhana dengan menggunakan program SPSS 16 karena program tersebut mudah diaplikasikan dianalisis oleh peneliti. Adapun hasil regresi sederhana terhadap faktor sosial ekonomi secara keseluruhan dapat dilihat pada Tabel berikut :

Tabel 3.Hasil Analisis Regresi Sederhana Pengaruh Rendahnya Harga Karet Terhadap Status Sosial Ekonomi di Daerah Penelitian.

\begin{tabular}{|c|l|c|c|c|c|}
\hline $\begin{array}{c}\mathrm{N} \\
\mathrm{o}\end{array}$ & Variabel & $\begin{array}{c}\text { Koefisien } \\
\text { Regresi } \\
(\mathrm{B})\end{array}$ & $\begin{array}{c}\text { Standar } \\
\text { Error } \\
(\mathrm{SB})\end{array}$ & Beta & $\begin{array}{c}\mathrm{t} \\
\text { hitung }\end{array}$ \\
\hline 1. & Constant & 47.869 & 3.759 & & 12.733 \\
\hline 2. & Harga & .329 & .101 & .361 & 3.257 \\
\hline
\end{tabular}

\begin{tabular}{|c|c|c|c|c|c|}
\hline $\begin{array}{c}\text { Rendah } \\
(\%)\end{array}$ & & & & & \\
\hline $\mathrm{R}^{2}$ & .130 & \multicolumn{3}{|l}{} \\
\hline F hitung & 10.609 \\
\hline F table & 3.976 & & & \\
\hline
\end{tabular}

Sumber : Data Olahan, 2017

Pada tabel 17 terlihat bahwa nilai $\mathrm{F}$ hitung $(10,609)>$ nilai $F$ tabel $(3,976)$ yang artinya bahwa variabel independen (rendahnya harga karet) berpengaruh terhadap ststus sosial ekonomi secara keseluruhan petani karet. Dari Tabel diperoleh nilai koefisien determinasi $\left(\mathrm{R}^{2}\right)$ sebesar 0,130 artinya bahwa pengaruh variabel (rendahnya harga karet) terhadap variabel (faktor sosial ekonomi yang diuji) adalah sebesar $13 \%$, sedangkan sisanya 87 $\%$ dipengaruhi oleh variabel lain di luar model. Adapun pengaruh masing-masing dari faktor sosial ekonomi tersebut adalah :

\section{Faktor Pendapatan}

Hasil analisis regresi sederhana terhadap faktor pendapatan dapat dilihat pada Tabel berikut.

Tabel 4.Hasil Analisis Regresi Sederhana Pengaruh Rendahnya Harga Karet Terhadap Pendpatan Petani Karet di Daerah Penelitian.

\begin{tabular}{|c|c|c|c|c|c|c|}
\hline No & Variabel & $\begin{array}{c}\text { Koefisien } \\
\text { Regresi } \\
\text { (B) }\end{array}$ & $\begin{array}{c}\text { Standar } \\
\text { Error } \\
(\mathrm{SB})\end{array}$ & Beta & $\begin{array}{c}\mathrm{t} \\
\text { hitung }\end{array}$ & $\begin{array}{c}\mathrm{t} \\
\text { tabel }\end{array}$ \\
\hline 1. & Constant & 42.116 & 7.724 & & 5.453 & \multirow[b]{2}{*}{1,993} \\
\hline 2. & $\begin{array}{l}\text { Harga } \\
\text { Rendah } \\
(\%)\end{array}$ & .186 & .087 & .246 & 2.134 & \\
\hline & $\mathrm{R}^{2}$ & .060 & & & & \\
\hline \multicolumn{2}{|c|}{$\mathrm{F}$ hitung } & 4.554 & & & & \\
\hline \multicolumn{2}{|c|}{ F table } & 3.976 & & & & \\
\hline
\end{tabular}

Sumber : Data Olahan, 2017

Pada tabel 4 terlihat bahwa nilai $\mathrm{F}$ hitung $(4,554)>$ nilai $F$ tabel $(3,976)$ yang artinya bahwa variabel independen (rendahnya harga karet) berpengaruh terhadap pendapatan petani karet. Dari Tabel diperoleh nilai koefisien determinasi $\left(\mathrm{R}^{2}\right)$ sebesar 0,060 artinya bahwa pengaruh variabel (rendahnya harga karet) terhadap variabel (pendapatan) adalah sebesar 6\%, sedangkan sisanya $94 \%$ dipengaruhi oleh variabel lain di luar model. Pada coefficients regresi (B) nilai Constant (a) tabeladalah 42,116 sedangkan nilai Harga rendah (b) adalah 0,186 sehingga 1,993persamaan regresi dapat ditulis: 
$\mathrm{Y}=42,116+0,186 \mathrm{X} 1$

Hasil analisis regresi dapat diketahui nilai koefisien regresi rendahnya harga karet yang digunakan pada analisis yang terdapat pada Tabel 17 diatas adalah sebesar 0,186 dengan nilai t hitung 2,134 dan nilai $t$ tabel 1,993. Data ini menejelaskan bahwa nilai $\mathrm{t}$ hitung $>\mathrm{t}$ tabel artinya variabel rendahnya harga karet berpengaruh terhadap pendapatan, selain itu pada tingkat kepercayaan $95 \%$ apabila harga rendah sama dengan nol (tidak ada perubahan), maka pendapatan sebesar 42,116, dan apabila harga naik atau meningkat sebesar 1 satuan maka akan meningkatkan pendapatan sebesar 0,186.

Berpengaruhnya rendah harga terhadapa pendapatan karena pendapatan menurut Suratiyah (2006) adalah selisih antara total penerimaan dengan total biaya. Sedangkan penerimaan didapat dari nilai uang yang diperoleh petani dari hasil kali jumlah produksi dengan harga satuan produksi. Sehingga dapat disimpulkan bahwa harga yang rendah akan berpengaruh terhadap penerimaan yang berdampak pada rendahnya pendapatan.

\section{Jenis Pekerjaan}

Hasil analisis regresi sederhana terhadap faktor pekerjaan sampingan dapat dilihat pada Tabel 5.

Tabel 5. Hasil Analisis Regresi Sederhana Pengaruh Rendahnya Harga Karet Terhadap Jenis Pekerjaan Petani Karet di Daerah Penelitian.

\begin{tabular}{|c|c|c|c|c|c|c|}
\hline $\begin{array}{l}\mathrm{N} \\
\mathrm{o}\end{array}$ & Variabel & $\begin{array}{l}\text { Koefisien } \\
\text { Regresi } \\
\text { (B) }\end{array}$ & $\begin{array}{l}\text { Standar } \\
\text { Error } \\
\text { (SB) }\end{array}$ & Beta & $\begin{array}{c}\mathrm{t} \\
\text { hitung }\end{array}$ & $\begin{array}{l}\text { Ayula Candra (2012) pekerjaan utama } \\
\text { t tabelepala rumah tangga sangat berpengaruh }\end{array}$ \\
\hline 1. & Constant & 97.432 & 22.336 & & 4.362 & terhadap tingkat kemiskinan suatu rumah \\
\hline 2. & $\begin{array}{l}\text { Harga } \\
\text { Rendah } \\
(\%)\end{array}$ & -.652 & .252 & -.293 & -2.584 & $\begin{array}{l}\text { 1,99tangga, hal ini dikarenakan tiap jenis } \\
\text { pelkerjaan memiliki tingkat upah yang }\end{array}$ \\
\hline & $\mathrm{R}^{2}$ & 0.086 & & & & \\
\hline
\end{tabular}

\begin{tabular}{|c|l|l|}
\hline F hitung & 6.678 & \\
\hline F table & 3.976 & \\
\hline
\end{tabular}

Sumber : Data Olahan, 2017

Pada tabel 5 terlihat bahwa nilai $\mathrm{F}$ hitung $(6,678)>$ nilai $F$ tabel $(3,976)$ yang artinya bahwa variabel independen (rendahnya harga karet) berpengaruh terhadap jenis pekerjaan petani karet. Dari Tabel diperoleh nilai koefisien determinasi $\left(\mathrm{R}^{2}\right)$ sebesar 0,086 artinya bahwa pengaruh variabel (rendahnya harga karet) terhadap variabel (pendapatan) adalah sebesar 8,6 \%, sedangkan sisanya $91,4 \%$ dipengaruhi oleh variabel lain di luar model.

Selain itu secara parsial berdasarkan hasil analisis regresi didapatakan thitung sebesar -2,584 lebih besar dari $t$ tabel 1,993 ( $\mathrm{t}$ hitung $>\mathrm{t}$ tabel) sehingga terima Ho dan tolak $\mathrm{H} 1$ yang artinya bahwa terdapat pengaruh yang significant rendahnya harga karet terhadap jenis pekerjaan. Tanda negatif pada model mengindikasikan bahwa jika harga tetap rendah (tidak ada perubahan), maka jenis pekerjaan yang dihasilkan sebesar 97,432 dan apabila harga naik atau meningkat sebesar 1 satuan maka akan petani sampel akan terus mengurangi jenis pekerjaan sebesar 0,652 .

Dengan rendahnya harga karet akan berpengaruh terhadap jenis pekerjaan. Pekerjaan utama sebagai petani karet tidak lagi mencukupi untuk kebutuhan pokok maka petani sampel mencari pekerjaan lain, namun jika harga karet meningkat atau harga karet kembali tinggi maka petani akan kembali bersemangat menjadi petani karet sebagai mata pencaharian utama.

Menurut Gounder, 2005 dalam Ayula Candra, 2012, jenis pekerjaan utama dalam rumah tangga merupakan faktor penentu besarnya pendapatan (dan pengeluaran) yang diterima oleh rumah tangga. Menurut Butar (2008) dalam Ayula Candra (2012) pekerjaan utama kepala rumah tangga sangat berpengaruh pekerjaan memiliki tingkat upah yang 
upah minimum yang akan diterima oleh pekerjanya lebih rendah dibandingkan pada sektor lain (seperti : industri) dan di Indonesia mayoritas kepala rumah tangga miskin cenderung bekerja pada sektor pertanian baik dalam sub sektor pertanian tanaman pangan, perkebunan maupun perikanan.

\section{Pemilikan Kekayaan}

Untuk mengetahui pengaruh rendahnya harga karet terhadap pemilikan kekayaan dan fasilitas, maka dilakukan analisis regresi sederhana. Untuk lebih jelasnya akan disajikan dalam Tabel 6 .

\section{Tabel 6. Hasil Analisis Regresi} Sederhana Pengaruh Rendahnya Harga Karet Terhadap Pemilikan Kekayaan di Daerah Penelitian.

\begin{tabular}{|c|c|c|c|c|c|c|}
\hline $\begin{array}{l}\mathrm{N} \\
\mathrm{O}\end{array}$ & Variabel & $\begin{array}{l}\text { Koe } \\
\text { fisien } \\
\text { Regre } \\
\text { si (B) }\end{array}$ & $\begin{array}{l}\text { Stan } \\
\text { dar } \\
\text { Error } \\
\text { (SB) }\end{array}$ & Beta & t hitung & $\begin{array}{c}\mathrm{t} \\
\text { table }\end{array}$ \\
\hline 1 & Constant & $\begin{array}{c}76.75 \\
3\end{array}$ & 9.477 & & 8.099 & \multirow{2}{*}{1,993} \\
\hline & $\begin{array}{l}\text { Harga } \\
\text { Rendah \%) }\end{array}$ & -.189 & .107 & -.205 & -1.765 & \\
\hline & $\mathrm{R}^{2}$ & 0.042 & & & & \\
\hline & F hitung & 3.117 & & & & \\
\hline & F table & 3.976 & & & & \\
\hline
\end{tabular}

Sumber : Data Olahan , 2017

Pada tabel 6 terlihat bahwa nilai $\mathrm{F}$ hitung $(3,117)<$ nilai $F$ tabel $(3,976)$ sehingga terima $\mathrm{H}_{0}$ tolak $\mathrm{H}_{1}$ yang artinya bahwa variabel independen (rendahnya harga karet) tidak berpengaruh terhadap pemilikan kakayaan dan fasilitas petani karet. Dari model regresi yang dihasilkan, diperoleh koefisien regresi rendahnya harga karet yang digunakan pada analisis yang terdapat pada tabel diatas adalah sebesar 0,189 dengan nilai $\mathrm{t}$ hitung $<$ dari $\mathrm{t}$ tabel ($1,765<1,993)$. Data ini menjelaskan bahwa rendahnya harga karet tidak mempengaruhi kepemilikan kekayaan dan fasilitas yang dimiliki petani dalam berusahatani karet. Selain itu pada tingkat kepercayaan $95 \%$ jika variabel lain dianggap konstan maka setiap penambahan satu satuan harga karet tidak akan diikuti oleh penurunan pemilikan kekayaan dan fasilitas yang dimiliki sebesar 0,189.

Harga karet yang rendah tidak berpengaruh terhadap kepemilikan kekayaan namun harga yang rendah berpengaruh terhadap pendapatan. Rendahnya harga berbading lurus dengan pendapatan. Peran pendapatan dari on farm cenderung semakin menurun dan pendapatan rumah tangga petani lebih terdiversifikasi, hal ini terutama berkaitan dengan menurunnnya skala kepemilikan dan pengusahaan lahan petani akibat dari konversi lahan pertanian, degradasi lahan dan tekanan penduduk. Kondisi ini berakibat adanya kecenderungan tingkat pendapatan usahatani tersebut tidak cukup untuk memenuhi kebutuhan rumah tangga dan upaya meningkatkan perbaikan pola konsumsi (Rachmat, 2013).

\section{Tingkat Pendidikan Anak}

Berdasarkan analasis regresi sederhana menyatakan bahwa rendahnya harga karet tidak memberikan pengaruh terhadap tingkat pendidikan anak di daerah penelitian. Untuk lebih jelasnya akan disajikan dalam Tabel 7.

Tabel 7.Hasil Analisis Regresi Sederhana Pengaruh Rendahnya Harga Karet Terhadap Tingkat Pendidikan Anak Petani Sampel di Daerah Penelitian.

\begin{tabular}{|c|c|c|c|c|c|c|}
\hline No & Variabel & $\begin{array}{l}\text { Koefisien } \\
\text { Regresi } \\
\text { (B) }\end{array}$ & $\begin{array}{l}\text { Standar } \\
\text { Error } \\
\text { (SB) }\end{array}$ & Beta & $\begin{array}{c}\mathrm{t} \\
\text { hitung }\end{array}$ & $\begin{array}{c}\mathrm{t} \\
\text { tabel }\end{array}$ \\
\hline 1. & Constant & 101.693 & 20.045 & & 5.073 & \multirow[b]{2}{*}{1,993} \\
\hline 2. & \begin{tabular}{|l|} 
Harga \\
Rendah \\
$(\%)$
\end{tabular} & -.390 & .227 & $\begin{array}{c}- \\
.200\end{array}$ & $\begin{array}{c}- \\
1.723\end{array}$ & \\
\hline & $\mathrm{R}^{2}$ & 0.040 & & & & \\
\hline & hitung & 2.970 & & & & \\
\hline & table & 3.976 & & & & \\
\hline
\end{tabular}

Sumber : Data Olahan, 2017

Table daiatas menunjukan bahwa nilai $\mathrm{F}$ hitung $(2,970)<$ nilai $\mathrm{F}$ tabel $(3,976)$ sehingga rendahnya harga karet tidak berpengaruh terhadap tingkat pendidikan anak petani sampel di daerah penelitan. Dari model regresi yang dihasilkan, diperoleh koefisien regresi rendahnya harga karet yang digunakan pada analisis yang terdapat pada tabel diatas adalah sebesar 0,390 dengan nilai $t$ hitung $<$ dari $t$ tabel ($1,723<1,993)$ sehingga rendahnya harga karet tidak mempengaruhi pendidikan anak yang dimiliki petani. Selain itu pada tingkat kepercayaan $95 \%$ jika variabel lain dianggap konstan maka setiap penambahan 
satu satuan harga karet tidak akan diikuti oleh penurunan pendidikan anak yang dimiliki petani sampel sebesar 0,390.

Rendahnya harga karet tidak berpengaruhnya terhadap tingkat pendidikan anak dari petani sampel diduga karena anak-anak petani sampel masih kecil-kecil sehingga belum cukup umur untuk menempuh pendidikan. Meskipun sebagaian besar $(50,68 \%)$ pendidikan petani sampel rendah yaitu setingkat SD namun kesadaran untuk menyekolahkan anak cukup baik hal ini terbukti dengan rendahnya harga jual karet, petani sampel tetap menyekolahkan anak-anak mereka. Selain itu tersedia sarana maupun fasilitas serta adanya program wajib sekolah 9 tahun dari pemerintah, menjadikan petani untuk bersemangat untuk menyekolahkan anakanak mereka. Kesedianan orang tua untuk menyekolahkan anaknya merupakan sarat mutlak bagi terlaksananya pendidikan bagi anak. Karena secara material dan moral orang tua mempengaruhi tingkat pendidikan anak-anaknya. Seperti yang disampaikan oleh Hasbullah (2009), salah satu tanggung jawab orang tua dan keluarga terhadap anak-anak mereka adalah memberikan ilmu pengetahuan dan keterampilan yang berguna bagi kehidupan anak kelak, sehingga bila ia telah dewasa akan mampu mandiri

\section{Kesehatan}

Hasil analisis regresi sederhana menunjukan bahwa tidak terdapat pengaruh rendahnya harga karet terhadap kesehatan petani sampel. Untuk lebih jelasnya dapat

dilhat pada Tabel berikut.

Tabel 8.Hasil Analisis Regresi Sederhana

\begin{tabular}{|c|c|c|}
\hline $\mathrm{R}^{2}$ & 0.001 & \\
\cline { 1 - 2 } $\mathrm{F}$ hitung & .097 & \\
\hline F table & 3.976 & \\
\hline
\end{tabular}

Sumber : Data Olahan, 2017

Tabel 8 mengindikasikan bahwa nilai $\mathrm{F}$ hitung $(0,097)<$ nilai $\mathrm{F}$ tabel $(3,976)$ sehingga rendahnya harga karet tidak berpengaruh terhadap tingkat kesehatan petani sampel di daerah penelitan. Dari model regresi yang dihasilkan, diperoleh koefisien regresi rendahnya harga karet yang digunakan pada analisis yang terdapat pada tabel diatas adalah sebesar $-0,035$ dengan nilai t hitung $<$ dari t tabel $(-0,312<$ 1,993) sehingga rendahnya harga karet tidak mempengaruhi pendidikan anak yang dimiliki petani. Selain itu pada tingkat kepercayaan 95\% jika variabel lain dianggap konstan maka setiap penambahan satu satuan harga karet tidak akan diikuti oleh penurunan tingkat kesehatan petani sampel sebesar 0,035 .

Berdasarkan hal uraian tentang pengaruh rendahnya harga terhadap faktor sosial ekonomi petani karet (pendapatan, jenis pekerjaan, pemilikan kekayaan, pendidikan anak dan kesehatan) maka dapat dilihat bahwa Jenis pekerjaan merupakan faktor sosial ekonomi yang paling dominan terpengaruh oleh rendahnya harga karet berdasarkan koefisien determinasi $\left(\mathrm{R}^{2}\right)$ sebesar 0,086. Untuk mengetahui faktor lebih dominan maka dilakukan analisis regresi linear berganda dengan menggunakan program SPSS. Hasil analisis regresi linear berganda akan disajikan pada Tabel 9.

Tabel 9. Hasil Analisis Regresi Berganda Pengaruh Rendah Harga Karet di Daerah Penelitian.

\begin{tabular}{|c|c|c|c|c|c|c|c|c|c|c|c|}
\hline \multicolumn{7}{|c|}{$\begin{array}{l}\text { Pengaruh Rendahnya Harga Karet Variabel } \\
\text { Terhadap Kesehatan Petani Sampel }{ }^{\circ} \text { di }\end{array}$} & \multirow{2}{*}{$\begin{array}{c}\begin{array}{c}\text { Koefisien } \\
\text { Regresi } \\
\text { (B) }\end{array} \\
72.258\end{array}$} & \multirow{2}{*}{$\begin{array}{c}\begin{array}{c}\text { Standar } \\
\text { Error } \\
\text { (SB) }\end{array} \\
14.176\end{array}$} & \multirow[t]{2}{*}{ Beta } & \multirow{2}{*}{$\begin{array}{c}\begin{array}{c}\mathbf{t} \\
\text { hitun } \\
\mathbf{g}\end{array} \\
5.097\end{array}$} & \multirow{2}{*}{ t tabel } \\
\hline Da & erah Pe & nelitia & & & 1 & Constant & & & & & \\
\hline $\begin{array}{l}\mathrm{N} \\
\mathrm{O}\end{array} \mid$ & Variabel & $\begin{array}{c}\text { Koe } \\
\text { fisien } \\
\text { Regresi }\end{array}$ & $\begin{array}{l}\text { Standar } \\
\text { Error }\end{array}$ & Beta & $\begin{array}{r}t \sqrt{2} \\
\text { hitung }\end{array}$ & $\begin{array}{l}\begin{array}{l}\text { Perfdapatan } \\
\text { otzape }\end{array} \\
\text { (\%ot) }\end{array}$ & .450 & .152 & .341 & 2.970 & \multirow{5}{*}{1,99} \\
\hline & & (B) & & & 3 & $\begin{array}{l}\text { Peklerjalan } \\
\text { Sampingan }\end{array}$ & -132 & 053 & -294 & -2512 & \\
\hline 1 & Constant & 74.343 & 10.061 & & 7.390 & $(\%)$ & & & & & \\
\hline \multirow{2}{*}{\multicolumn{2}{|c|}{\begin{tabular}{l|l|}
2 & $\begin{array}{l}\text { Harga } \\
\text { Rendah }\end{array}$ \\
& $\%)$ \\
\end{tabular}}} & \multirow[t]{2}{*}{-.035} & \multirow[t]{2}{*}{.114} & \multirow[t]{2}{*}{-.037} & \multirow[t]{2}{*}{$-.32^{6}$} & \begin{tabular}{|l|l} 
Pen? \\
Kekayaan (\%) \\
\end{tabular} & -.098 & .122 & -.091 & -.804 & \\
\hline & & & & & & Pendidjakan & -.106 & .066 & -.206 & -1.597 & \\
\hline
\end{tabular}




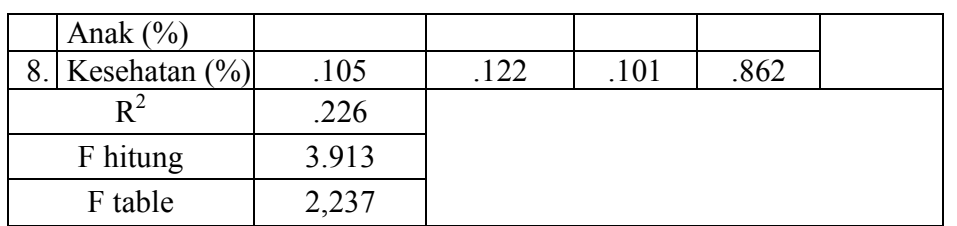

Sumber : Data Olahan, 2017

Faktor yang paling dominan terpengaruh oleh rendahnya harga karet dapat dilihat dari angka koefesien t hitung pada masing-masing varibel. Berdasarkan Tabel 23 diatas dapat dilihat bahwa pendapatan dengan koefesien t hitung 2.970 $>\mathrm{t}$ tabel 1,99 dan diikuti oleh pekerjaan sampingan dengan koefesien $\mathrm{t}$ hitung $2.512>\mathrm{t}$ tabel. Sedangkan variabel pemilikan kekayaan, pendidikan anak dan tngkat kesehatan petani sampel tidak terpengaruh akibat rendahnya harga karet.

Menurut Rachmat (2013), salah satu alat ukur kesejahteraan petani yang digunakan saat ini adalah Nilai Tukar Petani (NTP). NTP dihitung dari rasio harga yang diterima petani (HT) terhadap harga yang dibayar petani (HB). Jika harga yang diterima petani lebih kecil dari harga yang dibayar petani berakibat adanya kecenderungan tingkat pendapatan usahatani tersebut tidak cukup untuk memenuhi kebutuhan rumah tangga dan upaya meningkatkan perbaikan pola konsumsi. Kondisi ini mendorong anggota rumah tangga untuk mencari sumber pendapatan lain diluar kegiatan usahatani. Beberapa hasil kajiaan menunjukkan peran pendapatan dari non pertanian menunjukkan proporsi yang semakin meningkat. Peningkatan pendapatan dari non pertanian (non-farm) tersebut sejalan dengan terbukanya peluang usaha di kegiatan non pertanian akibat pertumbuhan ekonomi yang telah berjalan. Peningkatan lapangan kerja di luar bidang pertanian akan berdampak positif dalam diversifikasi sumber lapangan kerja dan pendapatan rumah tangga petani, dan kondisi ini berkontribusi positif dalam perluasan kesempatan kerja dan peningkatan pendapatan rumah tangga petani

\section{KESIMPULAN DAN SARAN}

\section{Kesimpulan}

Berdasarkan hasil analisis dan pembahasan pada bab sebelumnya maka dapat disimpulkan bahwa :

1. Pengaruh rendahnya harga karet terhadap status sosial ekonomi secara keseluruhan adalah kurang baik (persentase skor $=50,59 \%$ ). Sedangkan pengaruh rendahnya harga karet terhadap masing-masing status sosial ekonomi yaitu baik terhadap tingkat pendidikan anak (persentase skor 67,47 $\%$ dan kesehatan (persentase skor = $71,23 \%$ ), kurang baik terhadap faktor pendapatan (persentase skor $=43,84 \%$ ) dan kepemilikan kekayaan (persentase skor $=60,18 \%$ ) serta tidak baik terhadap jenis pekerjaan (persentase skor $=40,24 \%$ ).

2. Secara analisis regresi sederhana dan berganda rendahnya harga karet berpengaruh terhadap faktor sosial ekonomi secara keseluruhan ( $\mathrm{t}$ hitung $=$ $3,257>\mathrm{t}$ tabel $=1,993)$. Adapun faktor sosial ekonomi yang terpangaruh adalah pendapatan ( $\mathrm{t}$ hitung $=2,134>\mathrm{t}$ tabel $=$ 1,993) dan jenis pekerjaan ( $\mathrm{t}$ hitung $=$ $2585>\mathrm{t}$ tabel $=1,993)$ dan Jenis pekerjaan merupakan faktor sosial ekonomi yang paling dominan terpengaruh oleh rendahnya harga karet jika ditinjau dari nilai koefisien determinasi $\left(\mathrm{R}^{2}\right)$ sebesar 0,086 .

\section{Saran}

Untuk meningkatkan pendapatan dan memenuhi kebutuhan hidup petani karet, produktivitas karet yang tinggi dan kualitas karet baik juga harus diperhatikan serta perlu adanya perhatian dari pemerintah setempat dalam hal terutama dalam meningkatkan harga karet.

\section{DAFTAR PUSTAKA}

Abdulsyani. 2002. Sosiolor: Cistematika, Teori dan Terapan. P] Aksara. Jakarta

Arikunto, S. 2002. Prosedur Penelitian, Suatu Pendekatan Praktek. : PT. Rineka Cipta. Jakarta 
Ayula Candra, D.M.S. 2012. Pengaruh Kepemilikan Aset, Pendidikan, Pekerjaan Dan Jumlah Tanggungan Terhadap Kemiskinan Rumah Tangga Di Kecamatan Bonang Kabupaten Demak. Skripsi. Fakultas Ekonomika Dan Bisnis Universitas Diponegoro. Semarang.

Badan Pusat Statistik Kabupaten Bungo. Bungo Dalam Angka, Bungo In Figure 2015

Badan Pusat Statistik. 2013. Produksi Karet Dan Luas Lahan Perkebunan Karet di Indonesia

BPS. 2013. Sensus Pertanian. Jakarta

Dinas Perkebunan Dan Kehutanan Kabupaten Bungo, 2015. Luas Lahan dan Produksi Karet. Kabupaten Bungo.

Hasbullah, 2009. Dasar-Dasar Ilmu Pendidikan. PT. Raja Grafindo Persada. Jakarta.

Koentjoroningrat, 1989. Pengantar Ilmu Antropologi. Aksara Baru. Jakarta

Rachmat, M. 2013. Nilai Tukar Petani : Konsep, Pengukuran Dan Relevansinya Sebagai Indikator Kesejahteraan Petani. Forum Penelitian Agro Ekonomi, Volume 31 No. 2. Pusat Sosial Ekonomi dan Kebijakan Pertanian. Jakarta.

Sadono. S. 2002. Teori Mikro Ekonomi. CV. Rajawali. Jakarta

Setyamijaja, D. 1993. Karet. Kanisius. Yogyakarta

Singarimbun M. dan S. Effendi1989. Metode Penelitian Survey. LP3ES. Jakarta.
Soekanto. 2007. Teori Peranan. Bumi Aksara. Jakarta.

Soekartawi. 1988. Prinsip Dasar Ekonomi Pertanian. Raja Grafindo Persada. Jakarta

Sudjana. 2005. Metoda Statistika. Tarsito. Bandung

Sugiyono. 2013. Memahami Penelitian Kualitatif. Alfabeta. Bandung.

Suryana D.S. 2014 Hubungan Antara Faktor Sosial Ekonomi Dengan Persepsi Peternak Terhadap Pengembangan Usaha Peternakan Sapi Perah Di Kota Tomohon. Jurnal Zootek ("Zootrek" Journal ) Vol 34 No. 2 : 39-48 (Juli 2014) ISSN $0852-2626$.

Suyanto, B. 2005. Metode Penelitian Sosial : Berbagai Alternatif Pendekatan. Prenada Media. Jakarta

UPTD BP3K. Kecamatan Pelepat Kabupaten Bungo 2015. Luas Lahan dan Jumlah Keluarga Petani Karet. Pelepat . 